\title{
E se Deus existisse e morasse na Bélgica? Riso, humor e re- leituras das narrativas bíblicas
}

\section{What if God existed and lived Belgium? Laughter, humor and relief of bible narratives}

Vanda Fortuna Serafim*

Resumo: Deus, alcoólatra e perverso, criou o mundo não por amor, mas por tédio. Essa é uma das premissas do filme O Novíssimo Testamento (2014) dirigido e produzido pelo belga Jaco van Dormael. A narrativa fílmica abre uma série de reflexões sobre a relação entre deuses e humanos, deuses e deuses e humanos e humanos. Ele vive na Bélgica com sua esposa, passiva e quase sem voz e Ea, sua filha pré-adolescente, com um estilo clichê-gótico de rebeldia, entediada com a vida dos pais e a íntima relação com a televisão. O objetivo é perceber como as releituras das narrativas bíblicas do Cristianismo realizadas sugerem o riso e o humor na atualidade. Para tanto, parte-se metodologicamente das discussões realizadas por Marco Napolitano acerca do cinema como fonte histórica e teoricamente dialoga-se com Henri Bergson e Sigmund Freud para pensar o riso e o humor na narrativa fílmica.

Palavras-chave: Deuses e deusas; riso; humor; narrativa fílmica

\footnotetext{
* Professora Adjunta na Universidade Estadual de Maringá e docente do Programa de Pós-
} graduação em História (UEM), Brasil E-mail: vandaserafim@gmail.com 


\begin{abstract}
God, an alcoholic and a pervert, created the world not out of love but out of boredom. This is one of the premises of the film The New Testament (2014), it was directed and produced by the Belgian Jaco van Dormael. The film narrative opens a series of reflections on the relationship between gods and humans, gods and gods and humans and humans. He lives in Belgium with his wife, passive and almost voiceless, and Ea, his pre-adolescent daughter, with a cliché-Gothic style of rebellion, bored with her parents' lives and their close relationship with television. The goal is to see how the re-readings of the biblical narratives of Christianity that have been performed suggest laughter and humor today. For this, it is based methodologically on the discussions made by Marco Napolitano about cinema as a historical source and dialogues with Henri Bergson and Sigmund Freud to think laughter and humor in the film narrative.
\end{abstract}

Keywords: Gods and goddesses; laughter; humor; film narrative

Se não podemos compreender Deus nas suas obras visíveis, como então concebê-lo nos seus inconcebíveis pensamentos? Se não podemos compreendê-lo nas suas criaturas objetivas, como compreendêlo então nas suas disposições de animo substantivas e nas suas fases de criação? (Edgar Allan Poe).

\title{
1. A narrativa fílmica
}

O presente artigo analisa filme O novíssimo testamento ${ }^{I}$ (2014) dirigido e produzido pelo belga Jaco van Dormael. O intuito é perceber como as releituras das narrativas bíblicas do Cristianismo realizadas sugerem o riso e o humor na atualidade. Ao se partir de uma obra fílmica enquanto fonte histórica há certamente de se considerar que esta é, sem dúvidas, portadora de uma tensão entre evidência e representação. Nesse sentido é importante atentar à suas estruturas internas de linguagem e seus mecanismos de representação da realidade, analisando, a partir daí sua condição de "testemunho" de uma dada experiência histórica e social. Visa-se, portanto, empreender dois tipos de decodificação: a de natureza técnico-estética e a de natureza representacional, a primeira ligada à linguagem técnico-estética do cinema e a segunda, à realidade histórica ou social nela contidas ${ }^{2}$.

O novíssimo testamento, classificado como gênero comédia/fantasia, trata-se de uma coprodução entre a Bélgica, a França e Luxemburgo. O filme 
foi produzido em suporte fílmico digital pela companhia Terra Incognita Films e distribuído pela Le Pacte, com tempo de execução 113 minutos. A trilha sonora do filme foi elaborada An Pierlé e o roteiro contou com Thomas Gunzig, além do próprio diretor. Foi lançado originalmente em 17 de maio de 2015 (Cannes) e em 01 de setembro de 2015 na Bélgica, além de ter sido pré-selecionado entre os nove finalistas para disputar o Oscar de melhor filme estrangeiro, mas não indo, infelizmente à disputa.

Orçado em 8,7 milhões de euros, o filme faturou em bilheteria 154 milhões de euros. O filme foi lançado nos cinemas brasileiros em 21 de janeiro de 2016. O elenco do filme contou com Benoît Poelvoorde (Deus), Catherine Deneuve (Martine), François Damiens (François), Yolande Moreau (esposa de Deus), Pili Groyne (a filha de Deus, Ea), Laura Verlinden (Aurélie), Serge Larivière (Marc), David Murgia (Jesus Christ), Johan Leysen (esposo de Martine), Pascal Duquenne (Georges), Viviane De Muynck (mãe de Georges) e Johan Heldenbergh (padre).

O filme foi indicado, em diversas categorias, para festivais de cinema, tendo vencido como melhor filme no Belgian Film Critics Association, como maior audiência na Eupora e melhor filme no Biografilm Festival, melhor designer de produção no European Film Awards, melhor comédia no Fantastic Fest, levou o Prêmio Fedeora de melhor filme internacional no Haifa International Film Festival, o melhor filme em coprodução no Luxembourg Film Awards, melhor filme, diretor, trilha sonora original e roteiro no Magritte Awards, melhor filme fantástico europeu no Méliès d'Or, prêmio de audiência e especial do júri no Norwegian International Film Festival e de melhor atriz e melhor filme fantástico europeu no Sitges Film Festival.

O diretor Jaco Van Dormael ${ }^{3}$ (60 anos), nascido em Ixelles, Bélgica em 1957, tem atuado, desde os inícios de 1980, também como roteirista, dramaturgo, produtor e diretor de fotografia. Com temas sempre tratados de forma complexa, seus filmes são aclamados pela crítica e especialmente reconhecidos pela forma respeitosa e solidária que são retratadas as pessoas com deficiências físicas e mentais. Essa sensibilidade aparece na fonte que analisamos na construção do personagem Aurélie, que na infância tivera o braço amputado, passando a usar uma prótese.

Jaco Van Dormael foi criado na Alemanha até sete anos de idade, quando sua família retornou à Bélgica. Em seu nascimento, ele quase foi estrangulado pelo cordão umbilical e recebeu fornecimento insuficiente de oxigênio, gerando medo de que isso lhe causasse lesões e danos no desenvolvimento mental. Isto talvez explique porque os mundos de pessoas com deficiências físicas e mentais são recorrentemente explorados em seus temas.

Marcam sua trajetória o prazer em trabalhar com crianças, tendo sido, inclusive, palhaço de circo por um certo tempo, antes de desenvolver interesse por cinema e ingressar no Institut national supérieur des arts du spectacle et 
des techniques de diffusion (INSAS) e depois no Louis Lumière College, em Paris. Brincadeiras infantis, infância e inocência se tornaria fortes temas ao longo de sua obra.

$\mathrm{Na}$ década de 1980, Van Dormael produziu uma série de curtasmetragens que despertaram interesse crítico considerável. Dentre eles Maedeli la brèche (1981); Stade 81 (1982) Les voisins (1981), L'imitateur (1982), Sortie de secours (1983) e De boot (1985). Seu mais famoso curta do período é È pericoloso sporgersi (1984), que ganhou o Grand Prix na competição internacional no Festival Internacional de Curtas de Clermont-Ferrand. Como diretor, suas principais longas-metragens são Um homem com duas vidas (1991), O oitavo dia (1996), Mr. Nobody (2009) e O novíssimo testamento (2015). Sendo que o penúltimo foi o unico gravado em inglês, uma língua não belga, e que o projetou internacionalmente.

Sobre as temáticas exploradas por Van Dormael, há quase sempre o uso distintivo da narrativa ingênua e a análise do mundo de uma perspectiva inocente. Os pontos de vista dos personagens são muitas vezes coloridos, imaginativos, e um pouco distantes da realidade, com ligeiros elementos do imaginário surreal usados para ilustrar suas imaginações ativas.

Seus filmes também costumam terminar com uma morte, que é retratada não como uma tragédia, mas como movido prazeroso no qual o falecido olha feliz para o mundo abaixo. Entre o Céu e a Terra terminam com um nascimento, que é semelhante a uma passagem do personagem para um novo mundo, transmitindo uma sensação melancólica de felicidade. Van Dormael faz uso proeminente de músicas de padrões nostálgicos e todos os filmes de Van Dormael contém elementos surreais. $\mathrm{O}$ uso de personagens com deficiência, retratados cuidadosamente e a ênfase nas características infantis também marcam o trabalho do diretor.

\section{O novíssimo testamento}

Deus, alcoólatra e perverso, criou o mundo não por amor, mas por tédio. Essa é uma das premissas do filme que abrem uma série de reflexões sobre a relação entre deuses e humanos, deuses e deuses e humanos e humanos. Ele vive na Bélgica com sua esposa, passiva e quase sem voz e Ea, sua filha préadolescente, com um estilo clichê-gótico de rebeldia, entediada com a vida dos pais e a íntima relação com a televisão.

O pai, Deus, teria criado o mundo em seu escritório, um cômodo da casa, sempre trancado, rodeado por arquivos com os dados dos seres humanos e no centro dele, uma mesa, com um computador, bastante antigo, branco, um modelo da década de 90, embora o filme se passe na contemporaneidade. Deus criou o mundo como nós conhecemos a partir de Bruxelas, mas essa não 
foi sua primeira tentativa. Anteriormente as criaturas divinas que habitariam nosso mundo eram os animais, girafas e leões assistindo TVs e dirigindo carros. Descontente, Deus cria o homem e sente-se satisfeito com a criação, cujo primeiro ato é a alegria com a descoberta do próprio pênis. O filme abre espaço para uma série de discussões, como sexualidade, feminismo, autoritarismo, entre tantos outros. Para finalidade desta discussão nos centraremos nos evangelhos que subdividem as sequencias do filme.

Convém, todavia, destacar que o enigma de como o mundo veio a existir é um problema central para todas as mitologias.

Às vezes, o início de todas as coisas é descrito como um vazio ou vácuo total, ou alternativamente como uma vastidão ilimitada de água, um ermo indiferenciado envolto em escuridão - uma idéia comum às narrativas míticas do Oriente Médio, dos povos khoisan do sul da África e de muitas tradições da América do Norte e do Sudeste Asiático. No entanto, a imagem da criação mais amplamente disseminada representa o universo primitivo na forma de um ovo, contendo a potencialidade de tudo em sua casca plenamente envolvente. O padrão usual é que deve ocorrer algum tipo de ação que inicia um processo de mudança e desenvolvimento. Para o povo dogon, da África Ocidental, uma vibração desencadeada por Amma, o deus criador, rompeu os limites do ovo cósmico e libertou as divindades opostas da ordem e do caos. O ermo das águas descrito pelos cheyennes da América do Norte foi redimido por meio dos esforços da humilde gaivota aquática, que com seu bico salvou das profundezas um punhado de lama, o qual foi então transformado pelo Espírito de Tudo em terra seca. Uma história similar de pássaro prestativo, no caso a andorinha, na formação da primeira terra é contada nas ilhas do Sudeste Asiático. E no mito egípcio, o ato primordial da criação foi o surgimento de um outeiro com terra do abismo aquoso chamado Nun. ${ }^{4}$

Após ter descoberto que o pai controla o mundo pelo seu computador como uma forma de diversão, ou seja, criando uma série de leis para criar transtornos e estresses entre os humanos, atribuindo angustias e sofrimentos por puro sadismo e prejudicando as pessoas por escárnio, Ea, que se incomoda com as atitudes do pai recorre ao irmão J.C. (Jesus Cristo) para saber como fugir de casa e modificar tudo aquilo. Identificamos aqui, o primeiro ato de transgressão.

As transgressões são entendidas por Roy Willis ${ }^{5}$ como infrações na ordem tida como natural. 
Muitos mitos gregos falam sobre transgressores e seu castigo. Essas histórias podem ter sido contadas para ajudar a manter a ordem adequada das coisas, especialmente no seio da família, pois muitos mitos envolvem ultrapassar os limites da propriedade sexual. Quase todos têm protagonistas humanos, porque os deuses e as deusas geralmente podiam ter comportamento inadequado impunemente, enquanto os erros dos mortais eram habitualmente punidos com severidade - um paradoxo do qual os gregos antigos tinham consciência ${ }^{6}$.

O filme é narrado em primeira pessoa, na perspectiva de Ea que tenta descobrir um mundo diferente do seu e transformá-lo. Vemos aqui o que Roy Willis denominou as origens do infortúnio:

Independentemente de o mundo ter passado a existir por acidente ou desígnio, uma vez criado ele é visto em todas as mitologias como passível de mudança arbitrária. A causa de eventos imprevisíveis muitas vezes é imputada ao capricho de divindades aparentemente motivadas por emoções tão humanas quanto desejo sexual, raiva ou ciúme. No mito egípcio, o violento deus Seth criou devastação na terra assassinando seu irmão Osíris, de cuja alta reputação ele parecia ter ciúme. O rancor da deusa grega Éris ("disputa"), ofendida porque Zeus não a convidou para o casamento da ninfa do mar Tétis com o mortal Peleu, leva indiretamente à Guerra de Tróia. Na história da guerra, uma complicada série de eventos nos quais os protagonistas são seres divinos impelidos por motivos vis leva a grandes sofrimentos humanos e perda de vidas. A mitologia grega passa uma mensagem semelhante em seu relato de como o mal, na forma de doença e morte, veio ao mundo originalmente. Mais uma vez, esse desastre para a humanidade é visto aqui como o resultado de uma longa luta entre seres sobrenaturais (nesse caso, Prometeu e Zeus). O mito também explica a criação da primeira mulher, Pandora, como um estratagema de Zeus para ficar quites na briga com Prometeu. Enviada com um jarro selado (ou "caixa") ao irmão de Prometeu, Epimeteu, que a apresenta à sociedade humana, ela abre o jarro fatal por curiosidade, soltando no mundo seu calamitoso conteúdo de males, incluindo todo tipo de doenças; apenas a esperança permanece dentro do jarro. No decorrer desse mito, Prometeu aparece como o iniciador da civilização humana. ${ }^{7}$

Ea é a transgressora e causadora do infortúnio. A postura de indignação/ 
complacência com a mãe e repúdio do pai são evidentes. Seguindo os conselhos do irmão, EA rouba seis fichas aleatórias no arquivo de Deus para encontrar seus novos apóstolos, dando continuidade à obra do irmão. No filme, a organização do mundo é aleatória, sem interligações ou providencialismos, organizando-se pela simples vontade de Deus em extravasar suas frustrações se divertindo com os humanos. A forma que ela encontra de anular o poder do pai é enviando por mensagem de texto a data e hora exata da morte de cada pessoa. Assim, cada um passa a saber exatamente quanto tempo possui de vida, o que modifica em partes as ações, preocupações e pensamentos humanos.

A trama se divide em nove momentos, "Gênesis", o início, onde é apresentado a processo de criação do mundo. "Êxodo" que narra como ao descobrir as maldades do pai, Ea envia aos seres humanos a data de suas respectivas mortes. Pela máquina de lavar, Ea foge da casa do pai e chega ao mundo dos humanos. Logo encontra um morador de rua que ficaria encarregado de narrar a estória de cada apóstolo. Embora uma deusa, Ea tem poucos poderes, pois ainda não aprendeu com usá-los, seu principal dom é conhecer a música de dentro de cada pessoa, ao aproximar o ouvido de seu coração. Dessa maneira, Ea conhece as pessoas por dentro, pelo que possuem de mais íntimo e o que por vezes são incapazes de reconhecer.

Para estes dois primeiros momentos talvez seja coerente as reflexões de Henri Bergson na obra $O$ riso.

Que significa o riso? Que haverá no fundo do risível? Que haverá de comum entre uma careta de bufão, um trocadilho, um quadro de teatro burlesco e uma cena de fina comédia? Que destilação nos dará a essência, sempre a mesma, da qual tantos produtos variados retiram ou o odor indiscreto ou o delicado perfume? Os maiores pensadores, desde Aristóteles, aplicaram-se a esse pequeno problema, que sempre se furta ao empenho, se esquiva, escapa, e de novo se apresenta como impertinente desafio lançado à especulação filosófica. ${ }^{8}$

Mais do que definição a fantasia cômica, O novíssimo testamento traz antes de tudo, algo de vivo. Ainda que, a seu modo, até nos seus maiores desvios, metódico em sua insensatez, fantasiando, e evocando em sonho visões compreendidas por uma sociedade inteira, "acaso a fantasia cômica não nos informará sobre os processos de trabalho da imaginação humana, e mais particularmente da imaginação social, coletiva, popular? Fruto da vida real, aparentada à arte, acaso não dirá nada sobre a arte e a vida?",

Para Bergson o riso refere-se menos ao cômico propriamente que ao lugar onde devemos buscá-lo: o humano. Ver Deus à imagem e semelhança do homem que criou, em não necessariamente em seus melhores aspectos, 
ressalta a ideia de que não há comicidade fora do que é propriamente humano. Ao ir para o mundo atrás de Ea, os poderes de Deus são anulados, ele é um simples humano que para os demais, pensa que é Deus. Já não onipotente, onisciente e onipresente. É fraco, franzino, estúpido, arrogante e prepotente. Suas continuas tentativas de ser Deus sendo homem geram o riso e demonstram a "insensibilidade", assinalada por Bergson que naturalmente acompanha o riso. Nos divertimos com a desgraça de Deus, uma vez que ele seria responsável pelas nossas desgraças.

Mas esse riso se dá em cumplicidade, com Ea, com J.C e com a esposa de Deus. "Não desfrutaríamos o cômico se nos sentíssemos isolados"10. Tratando de um filme a ser exibido a um público, sabe-se que riso do espectador, no teatro, é tanto maior quanto mais cheia esteja a sala. Mas seriam os efeitos cômicos são traduzíveis de uma língua para outra, relativos, pois, aos costumes e às ideias de certa sociedade?

É interessante observar que a maior parte da premiação que o filme recebeu foi na Europa. Nos EUA, embora tenha participado de uma pré-seleção para concorrer ao Oscar de melhor filme estrangeiro, não chegou às vias de fato. Seria o expectador norte-americano menos inclinado a rir das desgraças de Deus? Ou da prepotência de pensar-se Deus sem sê-lo. O riso deve corresponder a certas exigências da vida em comum e deve ter uma significação social. As reflexões de Henri Bergson elucidam também as próximas partes do filme, divididas entre os evangelhos segundo os apóstolos de Ea: Aurélie, Jean-Claude, o obcecado sexual, o assassino, Martine e Willy.

\section{Os novos apóstolos}

\subsection{O evangelho segundo Aurélie}

Aurélie é a primeira apóstola de Ea. Uma moça muito bonita, mas incapaz de sorrir, quando criança, sofreu um acidente na estação de trem, perdendo um braço e passando a usar um protótipo de silicone. Na narrativa de Ea, onze homens no prédio em que vive são apaixonados por Aurélie, 274 querem transar com ela e todas as mulheres acham que ela "não passa de uma cadela no cio".

A história de Aurélie para o novíssimo testamento é sobre uma vez que estava no metrô e um morador de rua fétido, imundo e com péssima aparência se aproxima, ele imagina que vai lhe assaltar, xingar ou mostrar o pinto como geralmente acontece, mas ele diz "Minha, menina, a vida é como uma pista de gelo. Há muitas pessoas que caem". Essa frase marcou os pensamentos de Aurélie que se lembra dela cada vez que se olha no espelho.

O jogo de espelhos é um recurso técnico usado pelo diretor, seja para 
mostrar os estranhamentos que os personagens tem consigo mesmo, ou a forma deturpada que se enxergam e até mesmo o processo de reconciliação consigo mesmo.

\subsection{O evangelho segundo Jean Claude}

O segundo apóstolo de Ea foi durante muito tempo um aventureiro, depois parou e ninguém sabe por quê. Seguiu carreira burocrática e tinha uma "vidinha de merda". Até que soube que tinha o tempo que tinha de vida e jogou celular e a maleta fora. Sentou-se em um banco e decidiu nunca mais se mexer. Ficou observando os sons, os cheiros e a luz ao seu redor, como se pela primeira vez executasse os sentidos do corpo. Atento aos pássaros, ele passava grande tempo alimentando-os.

Nesse momento descobrimos mais dom de Ea, ela fala com os animais. Conversando com um pássaro que Jean-Claude admirava inicia-se o diálogo:

- Ele diz que gosta muito de você. Diz Ea.

- Por que ele fica só neste parque se pode voar para onde quiser? indaga Jean-Claude.

- Ele disse que a pergunta também é válida para você. Finaliza Ea.

Jean-Claude sai em uma nova aventura atrás do pássaro para o Ártico.

\subsection{O evangelho segundo o obcecado sexual.}

Embora se chamasse Marc, referia-se a si mesmo como 'obcecado sexual', passava o tempo em clube de streapers e desde que descobriu o tempo que possuía de vida decidiu gastar o dinheiro que poupava com uma prostituta por dia. Remetia sua postura à uma memória de infância. Quando obrigado ir com a família a um acampamento, visualizou uma adolescente, belíssima, em um biquíni azul turquesa, que surgia como uma miragem, tentou sorrir para ela e sentiu-se estúpido: "Tive vontade de comê-la e dei um sorriso bobo".

Desde então passou a viver cheio de pensamentos sexuais que não abandonavam sua mente, mesmo na sala de jantar com seus pais. É interessante pois nunca chama as mulheres que habitam sua mente pelo nome elas são sempre "a filha de ...". Embora treinasse na internet como interagir com as mulheres, sempre falhava, por isso preferia pagar com elas.

Numa cena chave, ele anda pelo supermercado com o carinho, enquanto as mulheres que fazem compras aparecem nuas, caminhando apenas com salto e seus acessórios. Ele sorri. Como se todas elas pudessem estar a sua disposição como produtos.

Ea o define como solitário. Ao dizer a ela que o dinheiro que tem não é suficiente para passar o resto dos dias com mulheres, ela sugere que ele use sua voz, que ela acha bonita, para trabalhar. E torna-se dublador de filme pornô. 
Sua colega de trabalho viria a ser a moça de biquíni turquesa, é quando ele conhece o amor e o respeito pela mulher, já não mais um produto.

\section{$1.4 O$ evangelho segundo o assassino}

No dia em que soube das datas das mortes, a primeira coisa que fez François foi comprar uma arma para atirar nas pessoas. "Estava escrito, François era apenas a mão do destino". Desde criança ele gostou da morte, adorava funerais. François nunca chorou ou sentiu tristeza e chamava a si próprio de o 'assassino'.

Em sua infầncia matava formigas, moscas, borboletas, ratos e periquitos. Foi quando ficou ciente da grande fronteira que separa o mundo dos vivos do mundo da morte. Aos 41 anos era casado e tinha um filho, mas não os amava. Era segundo Ea, uma vítima de uma das leis de Deus "se um dia se apaixonares por uma mulher há uma forte possibilidade de não passares a tua vida com ela".

Ea sugere que ele atire em uma mulher de cabelos castanhos, era Aurélie, que passaria por ali. A bala acerta o braço de silicone e ela não sente, o que o deixa intrigado. Ela se apaixona com ela e se reencontra consigo mesmo.

\subsection{O evangelho segundo Martine}

Martine desde a infância vivera um conto de fadas, como a Barbie que brincava na infância buscava a felicidade em sapatos, bolsas e maquiagem. Sempre esperou o príncipe encantado, mas só encontrou nos homens decepção. Inclusive no esposo, que pareceu satisfeito ao saber que teria muito mais tempo de vida que ela.

Ao ouvir a música interior de Martine, Ea diz a ela que é uma música de circo, e elas vão até um próximo. Ao se aproximarem da jaula do gorila, este e Martine se toca. "Ele diz que gosta de você" avisa Ea. "É a primeira vez que acontece me acontece algo tão bonito", afirma Martine, enquanto escorre uma lágrima.

Ela leva o gorila para casa e se relaciona com ele. Nele encontra o carinho e sentimento que não encontrou nos homens.

\subsection{O evangelho segundo Willy.}

"Willy foi meu milagre pessoal" diz Ea. Tratado como uma criança doente pela mãe acabou adoecendo de fato pelo excesso de zelo e remédios que ela o obrigava a tomar. Ele diz que com as datas da morte, apesar dos poucos dias de vida, tudo mudou para melhor. Seus pais permitiram que ele escolhesse 
como passar os últimos dias e ele decidiu tornar-se uma garota. Empodeirado em um vestido vermelho, seus dias começam a ter leveza.

No diálogo com Ea indaga "Seu pai tem poder?", "Ele tem apenas fome de poder", responde a garota. Ea mostra alguns pequenos milagres que sabe fazer multiplicando um sanduiche de presunto. Observando as crianças os novos apóstolos decidem que precisam ajudá-las.

\section{A recriação do mundo.}

É preciso destacar que os novos apóstolos e evangelhos nascem a partir de uma nova certeza eles vão morrer. É claro que todos os seres humanos sabem que um dia irão morrer, mas esta percepção tende a ser negada. Sobre este aspecto, Edgar Morin, em $O$ homem e a morte ${ }^{l 1}$, destaca que a morte é, à primeira vista, uma espécie de vida que se prolonga, de um modo ou de outro, a vida individual. De acordo com esta perspectiva, ela não é uma ideia, mas uma "imagem", uma metáfora da vida. Nos vocabulários mais arcaicos a morte não existe como conceito, fala-se em: sono, viagem, nascimento, doença, malefício, morada dos ancestrais ou tudo isso ao mesmo tempo. A mortalidade não supõe a ignorância da morte, mas o reconhecimento dela como um fato. $\mathrm{O}$ acontecimento da morte é percebido como uma mudança de estado, um "algo" que modifica a ordem normal da vida. A mesma consciência que nega, reconhece a morte: nega como aniquilamento e reconhece como um fato. Mas entre a descoberta da morte e a crença na imortalidade, no cerne desta indivisão originária, há uma zona de inquietude, de horror.

Assim, estabelecida a data e momento exato da morte aos personagens há a transformação de suas condutas. Na segunda-feira Willy vendeu os móveis dos pais porque as viagens são caras, e era dessa maneira que passaria seus últimos dias. Na terça-feira Aurélie pediu ao "assassino" que parasse de matar, ele diz ter perdido a vontade. Na quarta-feira Martine colocou sua vida em ordem e assumiu a sua relação com o gorila, mandando o marido embora. $\mathrm{Na}$ quinta-feira Marc e Xenia fazem amor pela primeira vez. E adoram! (E a mãe de Ea, a deusa, decide aproveitar o dia para lavar as janelas do apartamento). $\mathrm{Na}$ sexta-feira, Willy e Ea decidi que que chamariam os dias da semana de janeiro, fevereiro, março... Assim depois de sete dias, teriam vivido sete meses juntos! No sábado, Jean-Claude chegou ao círculo polar. E, Deus, que não possuía documentos foi deportado ao Uzbequistão.

O riso no filme, partindo de Freud ${ }^{12}$, refere-se menos ao cômico propriamente que ao lugar onde devemos buscá-lo, no humano. Como alerta Freud, é possível pensar no humor, quando este surge, quando um escritor ou narrador descreve o comportamento de pessoas reais ou imaginárias de modo humorístico. É o que parece acontecer com os apóstolos escolhidos por Ea. Embora não esteja pensando a narrativa fílmica, sua reflexão serve a nossa 
problematização à medida que alerta que essas próprias pessoas não precisam demonstrar humor algum; ou seja, a atitude humorística interessa apenas à pessoa que as está tomando como seu objeto. Assim, o expectador partilha da fruição do humor, a cada novo apóstolo apresentado e sua relação tragicômica com o mundo. A atitude humorística é possível de ser dirigida quer para o próprio eu do indivíduo (diretor) para outras pessoas (expectador).

O complexo da perda da individualidade é um complexo traumático, que comanda todas as perturbações provocadas pela morte, ao qual Morin chama de traumatismo da morte. Este não é importante que a consciência do fato da morte e a crença na imortalidade. Traumatismo da morte é toda a distância que separa a consciência da morte da aspiração à imortalidade. $\mathrm{O}$ homem poderia sentir esta emoção perturbadora se aderisse plenamente à sua imortalidade? A consciência da morte é uma consciência de perda de imortalidade. A individualidade que se revolta diante da morte é uma individualidade que se afirma contra da morte. A afirmação incondicional do indivíduo contra a morte entra em conflito com a afirmação do grupo social sobre o indivíduo ${ }^{13}$. Os seis apóstolos, vítimas de um Deus entediado, que cria os problemas na vida de suas criaturas como forma de distração, ao tomarem consciência dos desígnios de Deus, que não há vida após a morte e que o paraíso é aqui, permitem-se voltar-se a si mesmo. E no processo de descoberta e valorização de si, contribuem para a criação de um novo mundo.

Morin pretende mostrar que a vida animal implica muito menos a ignorância da morte que a adaptação à morte, isto é, a adaptação à espécie. Ao mesmo tempo em que ignora a morte, o animal reconhece o que seria uma morte-agressão, morte-perigo, morte-inimiga. “A consciência humana da morte não supõe apenas a consciência daquilo que era inconsciente no animal, e sim uma ruptura na relação indivíduo-espécie, uma decadência da espécie em relação à individualidade" 14 .

O instinto é também um formidável sistema de proteção contra o perigo da morte. "É a espécie que conhece a morte, não o indivíduo"15. A espécie existe através da morte de seus indivíduos. A maquinaria complexa das espécies evoluídas e sexuadas traz consigo a morte. A espécie se autoprotege, ao fazer morrer naturalmente seus indivíduos, ela salvaguarda seu próprio rejuvenescimento e também se protege da morte perigo ou agressão, graças a todo um sistema de instinto de proteção. No interior da espécie reina um tabu de proteção "os lobos não se devoram". Na medida em que a morte significa uma perda de individualidade, uma cegueira animal à morte, é uma cegueira à individualidade.

É a individualidade humana que se mostra lúcida diante de sua morte; tentando negá-la elabora o mito da imortalidade. A consciência da morte não é algo inato e sim o produto de uma consciência que capta o real. A morte humana é um conhecimento do indivíduo. Justamente por seu conhecimento da 
morte ser exterior e não inato que o homem é sempre surpreendido pela morte. $\mathrm{O}$ inconsciente é um conteúdo na qual se misturam a cegueira animal à morte e desejo humano de imortalidade (amortalidade). "Quando o homem banca o anjo imortal; não banca animal; ele banca o anjo para não bancar o animal. No máximo, em sua recusa enganadora da morte, ele bancará o imbecil"16.

"A canção das canções" é a última parte do filme, mas instaura também um novo início e nesse sentido, talvez corresponda visão de Freud ao nos alertar que os processos defensivos são correlativos psíquicos de um reflexo de fuga e realizam a tarefa de impedir a geração de desprazer a partir de fontes internas.

A narrativa final do filme se inicia com mãe de Ea limpando a casa feliz e enfeitada com flores, após a filha conseguir mais seis apóstolos, totalizando 18, seu número preferido, como o número de jogadores de baseball. Ao limpar o escritório do marido ela retira, para ligar o aspirador, o fio do computador da tomada.

É domingo. Todos estão na praia sentados em volta de Willy, que aguarda sua morte. Aquele seria seu último dia. Um avião começa a perder a altitude em direção à praia. Deus está dentro dele e se apavora. A mãe coloca a tomada do computador de volta e a máquina lhe pergunta "quer reiniciar?", cautelosamente ela se aproxima e digita "sim", o computador pede a senha e ela digita "18". Lê-se no computador: "Olá deusa, estou feliz em revê-la"! Ela sorri.

Sobre o culto a Grande Deusa, notamos desde o final do século XX um significativo revigoramento. Em 1974, em Minneapolis nos Estados Unidos, várias pessoas se reuniram para elaborar uma declaração contendo os princípios da crença Wicca, a religião da Grande Deusa, que atualmente reúne seguidores em todo mundo. Esse processo precisa ser compreendido em consonância com a preocupação cada mais maior com o destino do planeta, os movimentos ambientais e o reiterado discurso de destruição da natureza ${ }^{17}$.

Inana (Suméria), Nut (Egito), Freya (Nórdicos) e Afrodite (Grécia) são alguns exemplos de deusas relacionadas especialmente a fertilidade. As diversas representações da deusa mostram-na como portadora de um caráter forte, poderosa e dinâmica. Nesse sentido é interessante a construção da personagem feminina no decorrer do filme. Muda, passiva, insegura. Que em muito se afasta da forma como a imagem da deusa é representada na história das religiões, justamente em contraposição ao conceito equivocado de que o feminino é tranquilo, passivo ou inferior. A grande deusa está associada a vida que dá poderes, renovação, renascimento, transformação e com o mistério da morte $^{18}$. É o que encontramos ao final da narrativa fílmica.

O termo rever é interessantíssimo, não é a primeira vez que ela tem acesso ao computador e a criação do mundo. A mulher subordinada e sem voz durante o filme recria o mundo. Elimina as previsões de morte e colore o céu com flores, retira a gravidade, permite que as pessoas caminhem no fundo do 
mar como se estivessem na terra. Ela olhando para cima emocionada grita "É minha mãe. É a mamãe”. O mundo retorna a era da deusa Mãe.

\section{Reflexões finais.}

O riso e o humor no filme criam conexões entre história e literatura bíblica, pois como sugere Paul Ricouer ${ }^{19}$, possibilitam a autocrítica da memória coletiva, sendo a memória seletiva, auxiliado nesse aspeto pelas narrativas, implica que os mesmos acontecimentos não sejam memorizados da mesma forma em diferentes contextos históricos.

Juan Orellana ${ }^{20}$ (2005), no trabalho "La fuerza de la Biblia en el cine" destaca que muitos cineastas atentaram as escrituras bíblicas de diferentes formas. Mesmo depois de mais de um século de cinema, as escrituras seguem projetando a sua sombra sobre a sétima arte de formas diversas e, inclusive, opostas.

La Biblia es el mejor guión de la historia. Guión de guiones, hay en ella drama, tragedia, romance, guerras, gestas heróicas, e incluso thrillers, venganzas, adulterios, pasiones... La presencia de Dios em medio de los hombres nunca ha prescindido del abanico de possibilidades que brinda la libertad humana. No es casual que al primer tratamento guionizado de una serie televisiva larga se le llama en el argot «la biblia» de esa serie. Muchos cineastas se han acercado a las Escrituras buscando su esqueleto religioso, otros lo han hecho como quien se acerca a una gran historia épica, y por fin hay quienes han visto en ella un mito, al estilo de las grandes cosmogonías griegas $\mathrm{u}$ orientales.

Dentro as possibilidades elencadas pelo autor a aproximação paródica é a que parece estar mais diretamente ligada ao trabalho realizado por Dormael em $O$ novíssimo testamento.

Trata-se daquela que tem feito dos episódios bíblicos o motivo de gags ou filmes cômicos. Podem ser irreverentes, ou oferecer pontos de vista discordantes ou depreciativos questionando fatos bíblicos com, por exemplo, a ideia de que Deus criou o mundo porque era bom, ou que o deus cristão foi o primeiro e único deus, ou afirmando que o mal é produto de Deus e não algo que estava ali antes da criação do mundo.

Pode ainda oferecer uma leitura cientificista e deslegitimadora dos textos bíblicos. Mas de modo geral, cada vez mais se utilizam de elementos de origem bíblica de uma forma paganizada, ou tão superficial que resulta 
paródica (ORELLANA, 2005). Deus não é o todo poderoso, ele se quer tem poderes, não consegue fazer milagres. A sua autoridade está na manipulação por meio de um computador e na intervenção destrutora na vida das pessoas. Como um Deus assim se mantem no poder? Dentro de uma família patriarcal, onde a mãe, anteriormente Deusa, sofre abusos constantes e é silenciada. O filho, Jesus Cristo, tenta desafiar o pai, mas não se desvincula totalmente deste. É a filha, Ea, ocultada das narrativas que toma as dores da mãe, do irmão e de si mesmo, após ser espancada pelo pai pelo fato de questioná-lo, que subverte a ordem do pai. Ao instaurar ao caos, ela abre espaço para que a mãe reassuma o poder e se inicie uma nova era, mais colorida e leve.

Embora o filme não trate diretamente do fim do mundo, ao encerrar a idade do pai e retomar a era da Mãe, vemos fim e início de novos tempos, nesse sentido é relevante a observação de Orellana (2005) acerca da moda do cinema apolítico, no qual os referentes bíblicos e teológicos, se utilizam de uma forma nada cristã, mas ao contrário muito eclética.

Por fim, o tema mais difundido atualmente da forma paródica diz respeito ao diabo. Geralmente produzidos por pessoas que não creem em sua existência e utilizam da encarnação do Mal como um recurso para o filme de terror. Um cinema de concepção muito fatalista do mal, no qual a liberdade não tem espaço e que nunca finaliza com o bem (ORELLANA, 2005). Esse aspecto é muito interessante para pensarmos $O$ novissimo testamento e abre espaço para uma série de reflexões. Aqui, não existe diabo, senão Deus. Ele é responsável por todo mal e crueldade. Todavia, o filme acaba de forma leve. Embora o mal não seja destruído, ele foi minimizado, retirado de sua fonte de poder, embora siga buscando maneiras de reencontrá-la.

\section{Notas de Fim}

1 LE TOUT NOUVEAU TESTAMENT (O Novíssimo Testamento). Direção de Jaco van Dormael. Bélgica, a França e Luxemburgo. Produzido por Terra Incognita Films. 2014. 113 $\min$.

2 NAPOLITANO, Marcos. A história depois do papel. In: PINSKY, Carla Bassanezi (org.). Fontes Históricas. São Paulo: Contexto, 2006. pp. 235 - 290.

3 Informações sobre o diretor disponíveis em http://www.theinfolist.com/php/SummaryGet. php?FindGo=Jaco\%20van\%20Dormael . Acesso: 28/08/2016 e http://cinemajam.com/mag/ interviews/jaco-van-dormael Acesso? 20/08/2016.

4 WILLIS, Roy. (coord.) Mitologias. Deuses, heróis e xamãs nas tradições e lendas de todo o mundo. São Paulo: Publifolha, 2007. p.18.

5 Idem.

6 Ibidem, p.162

7 Ibidem, p. 22 
8 BERGSON, Henri. $O$ riso: ensaio sobre significações do cômico. $2^{\mathrm{a}}$ ed. Rio de Janeiro: Guanabara, 1987. P. 1.

9 Idem.

10 Ibidem, p.2.

11 MORIN, Edgar. O homem e a morte. Trad. Cleone Augusto Rodrigues. Rio de Janeiro, Imago, 1997.

12 FREUD, S. Os chistes e sua relação com o inconsciente [1905]. In:__.Edição standard brasileira das obras psicológicas completas. Rio de Janeiro: Imago, 1980. v. VIII.

13 MORIN, Edgar. O homem e a morte. Trad. Cleone Augusto Rodrigues. Rio de Janeiro, Imago, 1997.

14 Ibidem, p.56.

15 Ibidem, p.57.

16 Ibidem, p.56.

17 ANDRADE, Solange Ramos; SERAFIM, Vanda Fortuna; Costa, Daniel Lula; Palamin, Flávio. História das Religiões. Maringá, Eduem: 2013.

18 Idem

19 RICOUER, Paul. História e verdade. Trad. F. A. Ribeiro. Rio de Janeiro: Forense, 1968.

20 ORELLANA, Juan. La fuerza de la Biblia en el cine. La Sagrada Escritura, palabra actual: XXV Simposio Internacional de Teología de la Universidad de Navarra / edición dirigida por Gonzalo Aranda y Juan Luis Caballero, Servicio de Publicaciones de la Universidad de Navarra, 2005, pp. 183-190.

\section{Artigo recebido em maio de 2017. Aceito em julho de 2017.}

